\title{
ANK1 wt Allele
}

National Cancer Institute

\section{Source}

National Cancer Institute. ANK1 wt Allele. NCI Thesaurus. Code C84302.

Human ANK1 wild-type allele is located in the vicinity of 8p11.1 and is approximately 243

$\mathrm{kb}$ in length. This allele, which encodes ankyrin-1 protein, plays a role in erythrocyte

morphology. Mutation of the gene is associated with spherocytosis. 